\title{
Increasing the strength of destroyed wood of wooden architecture monuments by surface modification
}

\author{
Elena Pokrovskaya* \\ Moscow State University of Civil Engineering, Yaroslavskoe shosse, 26, Moscow, 129337, Russia
}

\begin{abstract}
The Anglican Church in Arkhangelsk built in 1833 represents a wooden architecture monument. The article describes the strengthening of partially destroyed samples of the Anglican Church wood by surface modification. The first layer of the sandwich coating is nitrilotrimethylphosphonic acid, which forms covalent bonds with the substrate, partially strengthening the wood. The second layer is an epoxy resin solution, which forms covalent bonds with the coating of the first layer, with hydroxyl groups of the first layer involved in the curing of the second layer as well. A two-layer surface coating is formed, while the strength of the wood increases by $2-2.5$ times, water absorption decreases by 3 times, and mass loss in combustion is no more than $9 \%$ according to GOST 27484-87. The monument preservation increases.
\end{abstract}

\section{Foreword}

Wooden architecture monuments represent an invaluable part of the national culture; they reflect the uniqueness and independence of native architecture. The problem of preserving the wooden architecture monuments with the course of time is becoming increasingly urgent. Many monuments burned; some of them collapsed due to loss of strength of their structures under the influence of humidity, biodeterioration, etc. [1-4]

According to the data from the Ministry of Culture of the Russian Federation, as of September 1, 2015, there are 7901 state protected objects in the territory of the Russian Federation which are wooden architecture monuments. A total of 1182 cases of lost wooden architecture monuments were recorded: 221 wooden architecture objects are in a good technical condition, 1790 objects are in unsatisfactory condition, and 621 objects are in emergency condition.

Increasing the strength of partially destroyed wood of monuments with the use of modern compounds and available technologies is a vital task.

The objects of research were the samples of partially destroyed wood of the Anglican Church in Arkhangelsk built in 1833. In 1852, after the fire, the church was rebuilt again in the Neo-Gothic style in the same place.[5-8]

\footnotetext{
* Corresponding author: elenapokrovskaya@bk.com
} 


\section{Materials and results}

In 2017, Princess Anne visited the Anglican Church during the celebration of the 75th anniversary of the first Arctic convoy.

According to the results of the survey of the Anglican Church in 2016, the decay of wood along the entire perimeter of the building, the presence of cracks, and the partial destruction of wood were identified. The survey was conducted by LLC Arkhstroyekspertiza.

To study the strengthening of the destroyed wood, samples of the Anglican Church sole timber were taken (Figure 1).

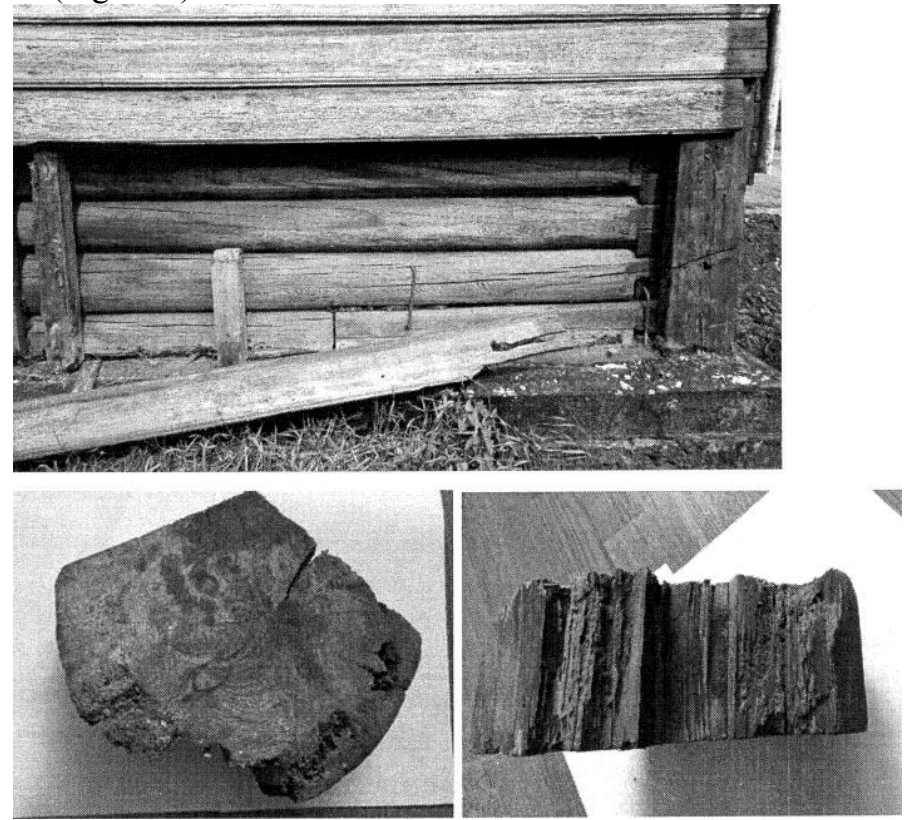

Fig. 1. The front of the Anglican Church. 15.02.2018

For the purpose of various tests, samples of the Anglican Church sole timber were sawn to the required dimensions in accordance with GOST 16483.11-72 and GOST 16483.3-84. When sawing, the straightness of the grain along the length parallel to its arbitrary faces was preserved where possible. The sizes of the samples depending on the test type are shown in Table 1.

Table 1. Sizes of the test samples.

\begin{tabular}{|l|l|}
\hline Sample sizes, $\mathrm{mm}$ & Test types \\
\hline $20 \times 20 \times 30$ & $\begin{array}{l}\text { Fire hazard tests, needle flame tests in accordance with GOST } \\
27484-87\end{array}$ \\
\hline $20 \times 20 \times 30$ & $\begin{array}{l}\text { Determination of conventional ultimate strength in compression } \\
\text { perpendicular to the grain in accordance with GOST 16483.11- } \\
72\end{array}$ \\
\hline $20 \times 20 \times 30$ & $\begin{array}{l}\text { Determination of conventional ultimate strength in compression } \\
\text { parallel to the grain in accordance with GOST 16483.10-73 }\end{array}$ \\
\hline $10 \times 10 \times 40$ & $\begin{array}{l}\text { Determination of ultimate static bending strength in accordance } \\
\text { with GOST 16483.3-84 }\end{array}$ \\
\hline $20 \times 20 \times 10$ & Water absorption \\
\hline $10 \times 10 \times 5$ & Infrared spectroscopy \\
\hline
\end{tabular}


The strength tests were carried out in accordance with GOST 16483.10-73 and GOST 16483.11-72 in the laboratory of Moscow State University of Civil Engineering using the Instron 3382 machine. The results are presented in Table 2.

Table 2. Determination of ultimate compression strength parallel and perpendicular to the grain of wood samples from the Anglican Church sole timber.

\begin{tabular}{|l|l|l|l|}
\hline No. & Compositions & $\begin{array}{l}\text { GOST 16483.10-73 } \\
\sigma 1 \quad \begin{array}{l}\text { MPa } \\
\text { compression parallel } \\
\text { to the grain }\end{array}\end{array}$ & $\begin{array}{l}\text { GO483.11-72 } \sigma \\
\text { MPa, compression } \\
\text { perpendicular to the } \\
\text { grain }\end{array}$ \\
\hline 0 & Native wood & 62.10 & 12.72 \\
\hline 1 & $\begin{array}{l}\text { Historical sample untreated with } \\
\text { formulations }\end{array}$ & 16.17 & 2.23 \\
\hline 2 & NTP 40\% & 24.91 & 5.17 \\
\hline 3 & Methylphosph. acid 40\% & 23.90 & 5.26 \\
\hline 4 & Boric acid 20\% & 22.51 & 4.36 \\
\hline 5 & NTP 40\%+ Akvidur TT 20\% & 38.84 & 5.84 \\
\hline 6 & $\begin{array}{l}\text { Methylphosph. acid 40\%+ Akvidur } \\
\text { TT 20\% }\end{array}$ & 36.93 & 6.17 \\
\hline 7 & Boric acid 20\% + Akvidur TT 20\% & 28.91 & 4.91 \\
\hline 8 & NTP 40\%+EP adhesive 20\% & 37.23 & 6.09 \\
\hline 9 & $\begin{array}{l}\text { Methylphosph. acid 40\% + EP } \\
\text { adhesive 20\% }\end{array}$ & 37.69 & 6.24 \\
\hline 10 & Boric acid + EP adhesive 20\% & 30.54 & 4.81 \\
\hline
\end{tabular}

Table 3 shows the results of determination of conventional ultimate strength in compression parallel to the grain in accordance with GOST 16483.3-84

Table 3. Determination of ultimate compression strength parallel to the grain of $\sigma 3 \mathrm{MPa}$ in the samples from the Anglican Church sole timber according to GOST 16483.3-84.

\begin{tabular}{|l|l|c|}
\hline No. & Sample & $\begin{array}{c}\text { GOST 16483.3-84 } \sigma 3 \\
\text { MPa, bending parallel to } \\
\text { the grain }\end{array}$ \\
\hline 0 & Native wood, untreated sample & 86.00 \\
\hline 1 & Anglican Church, untreated sample & 19.27 \\
\hline 2 & Anglican Church, NTP 40\% & 32.53 \\
\hline 3 & Anglican Church, MPA 40\% & 28.51 \\
\hline 4 & Anglican Church, NTP 40\%+ Akvidur TT 20\% & 32.17 \\
\hline 5 & Anglican Church, MPA 40\%+ Akvidur TT 20\% & 37.46 \\
\hline 6 & Anglican Church, NTP 40\% + EP adhesive 20\% & 40.08 \\
\hline 7 & Anglican Church, MPA 40\% + EP adhesive 20\% & 36.58 \\
\hline
\end{tabular}

Figure 2 shows the process of testing the samples. 

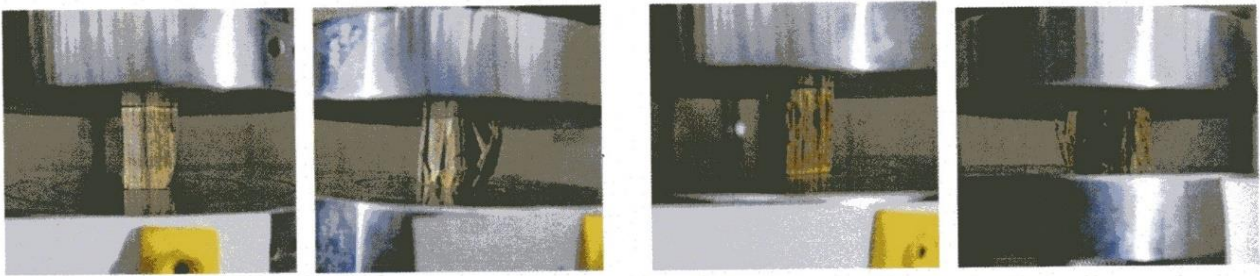

Fig. 2. Photographs of a test of treated wood from the Anglican Church sole timber during a compression testing parallel to the grain. On the left - untreated sample. On the right - the sample treated with NTP $40 \%$

Table 4. Increased strength of modified wood.

\begin{tabular}{|l|c|c|}
\hline & NTP 40\% & $\begin{array}{l}\text { NTP 40\% + EDP adhesive } \\
20 \%\end{array}$ \\
\hline Compression parallel to the grain, MPa & 1.5 & 2.3 \\
\hline Compression perpendicular to the grain, MPa & 2.5 & 2.7 \\
\hline Bending parallel to the grain, MPa & 1.68 & 2.09 \\
\hline
\end{tabular}

The study of modified samples of partially destroyed wood by infrared spectrometry (IR spectrometry) allow revealing the formation of new covalent bonds of the substrate with a modifier, which causes a significant increase in the strength of the samples. Figure 3 shows graphs of Fourier IR spectroscopy of the untreated sample of the Anglican Church sole timber, as well of the samples treated with NTP $40 \%$ and MPA 40\%. [9-12]

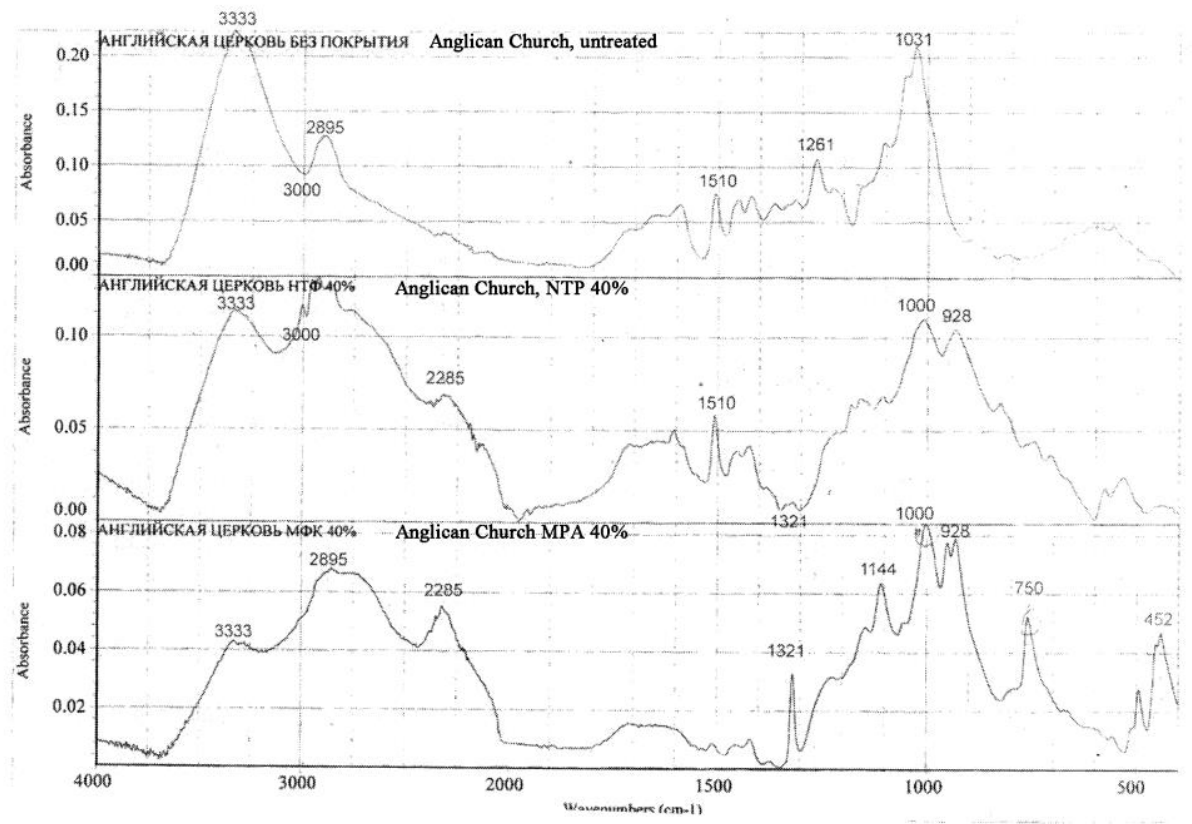

Fig. 3. Graphs of IR spectroscopy of samples of the Anglican Church sole timber

\section{Discussions}

Water absorption of the samples of the Anglican Church wood, modified with a sandwich coating. Wood is a heterocapillary system with capillary spaces of different sizes. The 
ability of wood to absorb moisture and retain it in the pores and capillaries is called water absorption. Water absorption of the wood significantly affects the durability, since surface hydrolytic destruction of the wood surface occurs in the presence of moisture. In the presence of biodegradators this process is significantly accelerated, which represents one of the main causes of wood destruction. Reducing the water absorption of historical wood is of great importance for the durability of wood structures and the preservation of historical monuments. The influence of modifiers on the water absorption of the samples of the Anglican Church wood was studied. Dependence of water absorption of the wood samples on the modifier type, and on the dwell time, is reflected by the corresponding graphs (Figure 4).

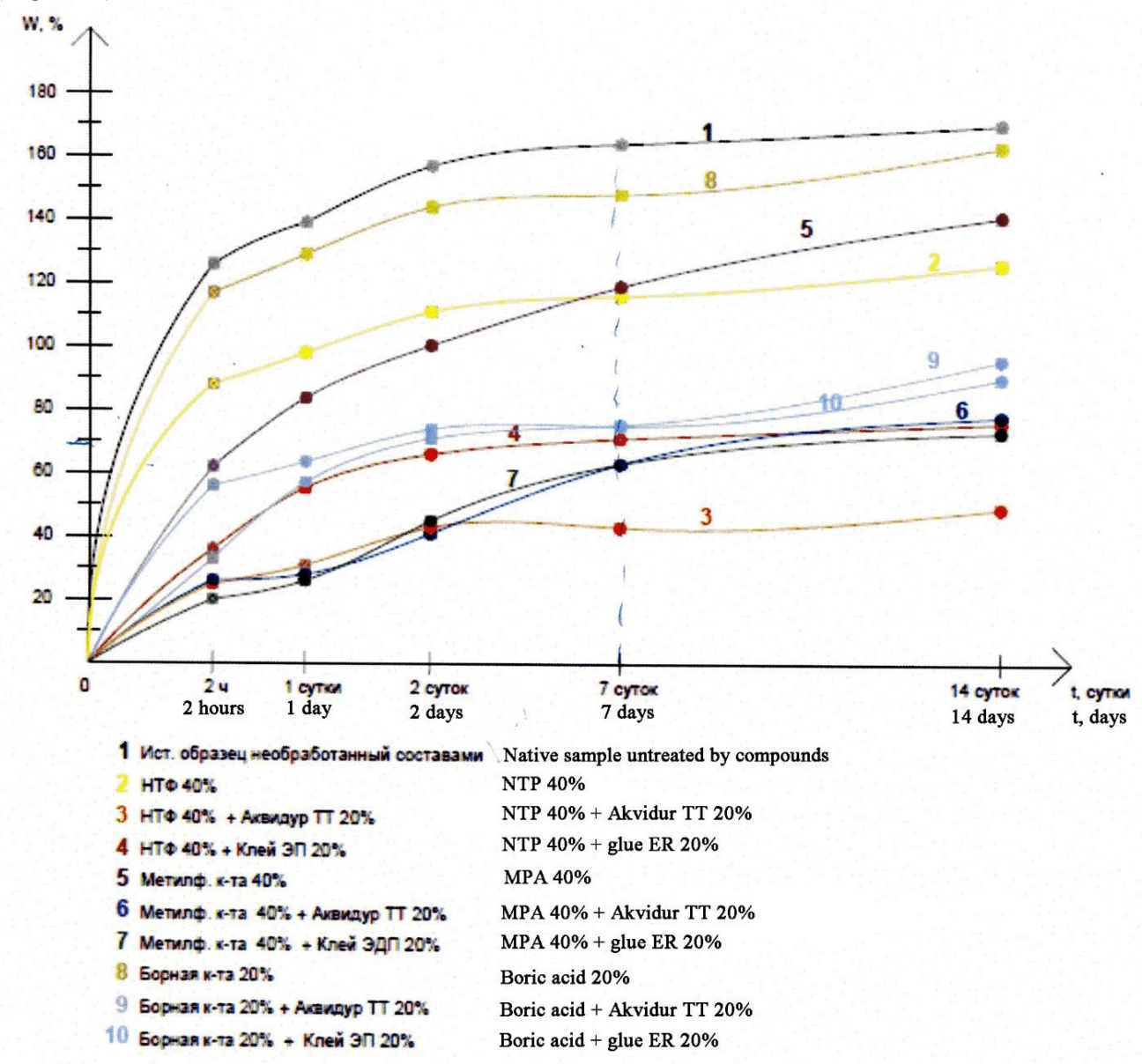

Fig. 4. The dependence of water absorption of the modified wood samples on the dwell time.

To determine the efficiency of the tested impregnating fire retardant agents, it was also necessary to determine the fire hazard of the partially destroyed wood. For this purpose needle flame tests in accordance with GOST 27484-86 were carried out. Initially, the samples were weighed.[13-18] Then, observations of the samples during exposure to fire for two minutes were performed. At the end of the test, the samples were weighed again, and the mass loss to be used for evaluation of the fire-proof efficiency group was calculated. The results are presented in Table 5. 
Table 5. The results of needle flame testing of the wood samples of the Anglican Church sole timber modified with $40 \%$ flame retardants, followed by coating with a $20 \%$ water repellent

\begin{tabular}{|c|c|c|c|c|c|}
\hline No. & Composition & $\mathrm{m}^{0}, \mathrm{~g}$ & $\mathrm{~m}^{1}, \mathrm{~g}$ & $\Delta \mathrm{m} \%$ & Remark \\
\hline 1 & Untreated sample & 5.42 & 2.08 & 61.62 & $\begin{array}{l}3 \text { min. } 24 \text { sec. of self- } \\
\text { burning; } 4 \text { min. } 18 \mathrm{sec} \text {. } \\
\text { of smoldering }\end{array}$ \\
\hline 2 & NTP $40 \%$ & 5.40 & 5.21 & 3.52 & no self-burning \\
\hline 3 & $\begin{array}{l}\text { NTP } 40 \%+\text { Akvidur TT } \\
20 \% \text { (2 layers) }\end{array}$ & 5.65 & 5.36 & 5.13 & no self-burning \\
\hline 4 & $\begin{array}{l}\text { NTP } 40 \%+\text { EP adhesive } \\
20 \% \text { (2 layers) }\end{array}$ & 4.34 & 4.12 & 5.07 & no self-burning \\
\hline 5 & NTP 40\% (2 layers) & 7.82 & 7.48 & 4.35 & no self-burning \\
\hline 6 & $\begin{array}{l}\text { NTP } 40 \%+\text { EP adhesive } \\
20 \% \text { (1 layer) }\end{array}$ & 1.71 & 1.6 & 6.43 & no self-burning \\
\hline
\end{tabular}

Under conditions of variable humidity, the wood of monuments is destroyed much faster. The destruction is accelerated by microorganisms, which are catalysts for hydrolytic destruction. With moistening and subsequent drying, cracks form, which reduce strength. Percentage characteristics of wood are determined by the content of cellulose. The destruction degree of a wood is characterized by the change in its cellulose content.

Based on the data given in Tables 2 and 3, the samples surface modified with sandwich coatings containing $40 \%$ of NTP and $20 \%$ of epoxy adhesive have the best strength characteristics. The quantitative increase in strength is determined by all parameters, see Table 4.

When analyzing the IR spectra of the untreated partially destroyed wood and the wood modified with NTP $40 \%$ and MPA $40 \%$, new bands appear in the absorption region of the characteristic frequencies of $2285 \mathrm{~cm}^{-1}$ and $928 \mathrm{~cm}^{-1}$. This indicates the formation of new covalent bonds of modifiers with the substrate.

When modifying the partially destroyed wood with boric acid, NTP and MPA modifiers, the water absorption decreases by $10 \%, 30 \%$ and $40 \%$ relative to the untreated wood. In a layer-by-layer treatment with water repellents and flame retardants, water absorption decreases by half, and the results insignificantly differ depending on the type of water repellent used, by $2-3 \%$ on average. The samples of the Anglican Church wood covered with methylphosphonic acid 40\% + EP adhesive 20\% and NTP + Akvidur TT 20\% have the lowest water absorption. Thus, in a layer-by-layer modification of wood with fire retardants and water repellents, a stable decrease in water absorption takes place.

The coatings tested have good fire-retardant properties, taking the wood to the first fireproof efficiency group - not more than $9 \%$ of the mass loss when tested in accordance with GOST 27484-86.

\section{Conclusions}

The restoration of the lost strength of a partially destroyed wood is possible with a surface modification by reactions with phosphorus-containing compounds and application of a second polymer layer, for example a $20 \%$ epoxy layer. The internal phosphorus-containing layer must enter into absorption chemical interactions with the epoxy layer of the sandwich coating. The developed sandwich coatings increase the wood strength $2-2.5$ times, and water absorption decreases by 2.53 times. The treated wood joins the first fire-proof efficiency group, and also it gets antiseptic properties. The obtained results allow increasing the durability of wooden structures and contributing to the preservation of wooden 
architecture monuments. The obtained materials were sent to LLC Arkhstroyekspertiza, Arkhangelsk.

\section{References}

1. M-LE. Florian Scope and history of archaeological wood. In: Rowell R.M., Barbour R.J. (eds.) Archaeological wood: properties, chemistry, and preservation / Advances in chemistry series, American Chemical society. Washington DC. pp. 3-32. URL: http://www.worldcat.org/title/archaeological-wood-properties-chemistry-andpreservation/oclc/454236315 (1990)

2. M. Matsuo, M. Yokoyama, K. Umemura Aging of wood: Analysis of color change during natural aging and heat treatment, Holzforchung, 65. pp. 361-368. URL:https://www.researchgate.net/publication/267803583_Aging_of_wood_Analysis_ of_color_changes_during_natural_aging_and_heat_treatment (2011)

3. H. Yorur, S. Kurt, H.I. Yumrutas The effect of aging on various physical and mechanical properties of scotch pine wood used in construction of historical safranbolu houses, Drvna Industrija, 3, pp. 191-196. (2014)

4. Bjordal C. G. Microbial degradation of waterlogged archeological wood, Journal of cultural Heritage, 13, pp. 118-122, (2012)

5. N.B. Pedersen, C.G. Bjordal, P. Jensen, C. Felby Bacterial degradation of archaeological wood in anoxic waterlogged environment, Harding S.E. (ed.) Stability of complex carbohydrate structures: Biofuels, foods, vaccines and shipwrecks. pp. 160-187. URL: http://pubs.rsc.org/en/content/chapter/bk9781849735636-00160/978-184973-563-6 (2013)

6. E.N. Pokrovskaya, Yu.L. Kovalchuk Biocorrosion, preservation of historical and cultural monuments, 212 p. URL: https://www.twirpx.com/file/1765425/ (2013)

7. E.N. Pokrovskaya Preservation of monuments of wooden architecture with the help of organoelement compounds. Chemical and physical basis for increasing the longevity of wood. 136 p. URL: https://search.rsl.ru/ru/record/02000011031 (2009)

8. E.L. Knut, L. Marstein Conservation of historic timber structures: An ecological approach, 140 p. URL: http://openarchive.icomos.org/1656/ (2016)

9. A.Kh. Kuptsov, G.N. Zhizhin Fourier-Raman spectra and Fourier-IR spectra of polymers, 696 p. URL: https://www.twirpx.com/file/375141/ (2013)

10. N. Belgacem Recent advances on surface chemical modification on polysaccharides: from basic consideration to concrete applications, Proceedings of International conference "Renewable resources: chemistry, technology, medicine» P. 25. URL: http://www.onlinereg.ru/rr2017/FINAL.pdf (2017)

11. E.N. Pokrovskaya, Yu.L. Kovalchuk Chemical-Mycological Method of Investigation of Wood, Modern Problems of Biological and Technical Wood Science. Collection of proceedings of the First International Scientific and Practical Conference. pp. 16-19. URL: https://search.rsl.ru/ru/record/01008642113 (2016)

12. E.N. Pokrovskaya, A.A. Kobelev Composition and properties of the layer of the carbonaceous layer formed in the combustion of wood modified by phosphorus and silicone compounds, Proceedings of the Moscow State University of Civil Engineering, 3, pp. 128-133. URL: https://cyberleninka.ru/article/n/sostav-i-svoystva-uglistogosloya-obrazuyuschegosya-pri-gorenii-drevesiny-modifitsirovannoy-fosfor-ikremniyorganicheskimi (2008) 
13. R.M. Aseeva, B.B. Serkov, A.B. Sivenkov Combustion of wood and its fire hazard properties, 262 p. URL: https://cyberleninka.ru/article/n/gorenie-i-pozharnayaopasnost-drevesiny (2010)

14. E.A. Anokhin, E.Yu. Polischuk, A.V. Savinkov Fire danger of enclosing wooden structures with a long service life, Fire and explosion safety, 10, pp. 30-40. URL: https://cyberleninka.ru/article /n/pozharnaya-opasnost-ograzhdayuschih-derevyannyhkonstruktsiy-s-dlitelnym-srokom-ekspluatatsii (2016)

15. E.N. Pokrovskaya Obtaining biostable materials for surface modification of wood, Proceedings of the Moscow State University of Civil Engineering, 7. pp. 636-640. URL: https://cyberleninka.ru/article/n/poluchenie-biostoykih-materialov-pripoverhnostnoy-modifikatsii-drevesiny-1 (2011)

16. E.N. Pokrovskaya, I.N. Chistov, R.A. Sheptalin Sandwich coatings on wood using nanocomposites, Building Materials, 7, pp. 78-81. URL: https://cyberleninka.ru/article/n/issledovanie-s-pomoschyu-ik-furie-spektroskopiireaktsiy-vzaimodeystviya-kompozitsiy-na-osnove-fosfororganicheskih-soedineniy-i (2010)

17. S.V. Afanasyev, V.M.Balakin Theory and practice of fire protection of wood and wood products, 138 p. URL: https://search.rsl.ru/ru/record/01008112928 (2012)

18. B.M. Tarasevich IR spectra of the main classes of organic compounds, 54 p. URL: https://www.freedocs.xyz/pdf-439081528 (2012) 